\title{
The Strange Career of the Reconstruction
}

\section{Amendments}

\author{
Eric Foner ${ }^{\dagger}$
}

As a historian who has devoted much of my scholarly career to the era of Reconstruction, I am most gratified that Bruce Ackerman has helped to resurrect the significance of those years as a central turning point in American constitutional development. ${ }^{1}$ As far as it goes, I have no real quarrel with his narrative of the events surrounding the rewriting of the Constitution during Reconstruction. To be sure, if stripped of Ackerman's distinctive rhetoric - constitutional impasse, consolidating election, and the like-his account will be quite familiar to scholars of the period. Even experts, however, will be enlightened by his careful attention to the nuances of presidential texts and congressional debates. I commend Ackerman, in this age of social history, for reasserting the importance of careful study of Washington politics, and for his willingness to confront unflinchingly the ambiguities surrounding the ratification of the Reconstruction Amendments. My quarrel with Ackerman's account of Reconstruction derives from what I consider an excessively narrow definition of both the process of constitutional change and the historical actors who helped to produce it.

In the two volumes of We the People, Ackerman divides American history into long periods of normal politics, and three moments of constitutional change. While it would be unfair to ask him to deal with the long periods of "normality" in the same detail as the constitutional moments, his almost complete neglect of the periods preceding and following his three pivotal eras leads, I think, to a distortion of both the catalysts and the enduring legacy of change. In the case of Reconstruction, I do not think that a reader of Ackerman's account would fully understand either the origins of the Thirteenth, Fourteenth, and Fifteen Amendments, or the reasons why two of them were substantially nullified in the decades that followed their ratification.

$\dagger$ DelWitt Clinton Professor of History, Columbia University.

1. See 1 BRUCE ACKERMAN, WE THE PEOPLE: FOUNDATIONS 81-103 (1991); 2 BRUCE ACKERMAN, WE THE PEOPLE: TRANSFORMATIONS 99-207 (1998). 
Perhaps the dichotomy of normal and constitutional politics is simply too schematic to encompass the actual historical processes by which alternative constitutional visions have in fact arisen, or the importance of incremental changes and relatively obscure individuals in the narrative of constitutional change. If the Constitution is not a text but a state of mind, as Ackerman contends, constitutional change is taking place constantly. Certainly, the pre-Civil War years were filled with debates over the Constitution, debates that powerfully influenced the actions of the ThirtyEighth and Thirty-Ninth Congresses. ${ }^{2}$ One cannot explain either the intellectual roots or the specific language of the Reconstruction Amendments without devoting some attention to the antebellum era, and especially to the abolitionist movement.

The long contest over slavery gave new meaning to such key ideas as personal liberty, political community, and the rights attached to American citizenship. In elaborating their criticism of slavery and attempting to reinvigorate the idea of freedom as a truly universal entitlement, the abolitionists developed what might be called an alternative constitutionalism. Even as slavery spawned a racialized definition of American democracy and citizenship that became increasingly hegemonic in the prewar years, the struggle for abolition gave rise to its opposite, a purely civic understanding of nationhood. The origins of the idea of an American people unbounded by race lie not with the Founders, who by and large made their peace with slavery, but with the abolitionists. The antislavery crusade insisted on the "Americanness" of slaves and free blacks, a position summarized, for example, in the title of Lydia Maria Child's popular treatise of 1833, An Appeal in Favor of that Class of Americans Called Africans. Child's text insisted that blacks were compatriots, not foreigners; they were no more Africans than whites were Englishmen. At a time when the authority to define the rights of citizens lay almost entirely with the states, and when the idea that blacks could never be genuine Americans grew in strength (to be ratified by the Supreme Court in Dred Scott), abolitionists maintained that "birth-place" should determine who was an American. ${ }^{3}$ This idea of birthright citizenship, later enshrined in the Fourteenth Amendment, was a truly radical departure from the traditions of American life.

Angelina Grimké, the daughter of a South Carolina slaveholder and a prominent abolitionist and feminist, wrote that the crusade against slavery was the nation's preeminent "school in which human rights are...

2. See WILliam M. WIECEK, THE SOURCES of ANTISLAVERY CONSTITUTIONALISM IN AMERICA, 1760-1848, at 249-60 (1977).

3. See Celeste Michelle Condit \& John louts lucaites, Crafting Equality: AMERICA'S ANGLO-AFRICAN WORD 84-97 (1993). 
investigated." ${ }^{4}$ Even as they debated the Constitution's relationship to slavery (William Lloyd Garrison burned the document, calling it a covenant with the devil; Frederick Douglass came to believe it offered no national protection to slavery), abolitionists sought to define the core rights to which all Americans were entitled. ${ }^{5}$ Abolitionists invented the concept of equality before the law regardless of race, one all but unknown in antebellum American jurisprudence. Before the Civil War, the movement was thoroughly alienated from a succession of administrations that seemed firmly in the grasp of the "Slave Power" (as antislavery Northerners came to call the planter class). Yet, in the ideas of a national citizenship and of equal rights for all Americans, abolitionists developed a constitutional outlook that would flourish during and after the Civil War. They glimpsed the possibility that the national state might become the guarantor of freedom, rather than its enemy, another idea written into the Constitution during Reconstruction.

Thus, the antebellum years were ones of constitutional fermentoutside of Congress if not within it-a ferment belied by Ackerman's categorization of the period as one of "normal politics" and also obscured by his single-minded focus on presidents and congressmen as the agents of constitutional change, with an amorphous body called "the People" occasionally stepping in to ratify what they have accomplished. So too were the Civil War years themselves. One group studiously ignored in the book is the former slaves, who, as I and others have argued, helped to place the issues of emancipation, equal citizenship, and manhood suffrage on the Reconstruction agenda by abandoning the plantations during the war and forthrightly demanding a new definition of American nationality after it. $^{6}$ So too, the principle of a national citizenship whose members enjoyed the equal protection of the laws, regardless of race, was powerfully reinforced by the service of 200,000 black men in the Union army, which placed the question of black citizenship on the national agenda. ${ }^{7}$ Here is another group of historical "actors" who played a part in rewriting the Constitution but are ignored in Ackerman's account. This neglect is particularly disturbing in a work that invokes "the people" as the ultimate arbiters of constitutional change, since one of the fundamental issues around which Reconstruction revolved was who in fact were the American people-that

4. ANGelina E. Grimké \& SARAh M. GRIMKE, The PUblic Years of SARAH and ANGELINA GRIMKÉ: SELECTED WRTINGS 1835-1839, at 194 (Larry Ceplair ed., 1989). 67.

5. See Eric Foner, Blacks and the U.S. Constitution, NEw LEFT REV., Sept.-Oct. 1990, at 63,

6. See ERIC FONER, RECONSTRUCTION: AMERICA'S UNFINISHED REVOLUTION 1863-1877 (1988); FREEDOM: A DOCUMENTARY HISTORY OF EMANCIPATION (Ira Berlin et al. eds., 1982).

7. See FONER, supra note 6, at 7-10. 
is, whether the racial boundaries that defined the "people" before the war should now be dismantled.

My point is that the initiative for the onset of Ackerman's second moment of constitutional politics arose not simply from the need to secure permanently the abolition of slavery, nor from the developing impasse between President Johnson and Congress, but from the larger society. Without an account of this broad context, it is impossible to understand how and why a consensus emerged within the Republican party that race should not limit the rights of citizenship and that civil equality and manhood suffrage were essential attributes of freedom. ${ }^{8}$ In a remarkable, if temporary, reversal of political traditions, Congress now sought to identify and protect the equal rights of all Americans. The Amendments and civil rights laws of Reconstruction reflected the intersection of the two products of the Civil War era-the newly empowered national state and the idea of a national citizenship enjoying equality before the law. Neither can be fully understood by looking solely at congressional deliberations and presidential politics.

It is tempting to view the expansion of citizens' rights during Reconstruction as the logical fulfillment of a vision articulated by the Founding Fathers but for pragmatic reasons not actually implemented when the Constitution was drafted. Yet, boundaries of exclusion had long been intrinsic to the meaning of American freedom. Reconstruction represented less a fulfillment of the Revolution's principles than a radical repudiation of the nation's actual practice for the previous seven decades. Indeed, it was precisely for this reason that the era's laws and constitutional amendments aroused such bitter opposition. The underlying principles-that the federal government possessed the power to define and protect citizens' rights, and that blacks were equal members of the body politic-were striking departures in American law. President Andrew Johnson, who vetoed bill after bill only to see them reenacted by Congress, claimed with some justification that federal protection of blacks' civil rights, together with the broad conception of national power that lay behind it, violated "all our experience as a people." 9 The Reconstruction amendments transformed the Constitution from a document primarily concerned with federal-state relations and the rights of property into a vehicle through which members of vulnerable minorities could stake a claim to substantive freedom and seek protection against misconduct by all levels of government. Ackerman is quite right to view Reconstruction as a moment of revolutionary change, but as I have noted, his focus on political procedures and electoral victories

8. See ERIC FONER, THE STORY OF AMERICAN FREEDOM 104-06 (1998).

9. See FONER, supra note 6, at 250. 
makes it impossible to comprehend fully either the nature of the revolution or the full cast of characters that helped to bring it about.

Ackerman says surprisingly little about the substantive changes in the Constitution brought about during Reconstruction, preferring to focus instead on the ratification process. He does not offer his own interpretation of those maddeningly ambiguous phrases, "due process" and "equal protection." He does not address the debate over whether the Fourteenth Amendment was intended to "incorporate" the Bill of Rights. This omission makes it very difficult to judge when and whether these Amendments achieved "legitimation."

For if Reconstruction was, constitutionally speaking, a revolution, it was in many ways an abortive one. And one of the most problematic features of Ackerman's account is his unwillingness to consider why the Fourteenth and Fifteenth Amendments so quickly became dead letters in much of the country. As is well known, by the 1880 s and 1890s, "liberty of contract," not equality before the law for blacks, came to be defined as the enduring meaning of both emancipation and the Fourteenth Amendment. ${ }^{10}$ For decades thereafter, the courts consistently viewed state regulation of business enterprise-especially interventions in contractual labor relations such as laws establishing maximum hours of work and safe working conditions-as a paternalistic insult to free labor, a throwback to the thinking characteristic of slavery. One might say that the "free labor" element of the Fourteenth Amendment-at least in one interpretation of free labor-was written into constitutional practice, but the racial dimension fell by the wayside.

In the longest footnote in Volume Two of We the People ${ }^{11}$ Ackerman marshals his considerable argumentative skills to refute the claim of Michael McConnell that a fourth "Constitutional Moment" occurred in 1876 with the abandonment of Reconstruction-the establishment of a Jim Crow republic in which racial inequality was reestablished as the prevailing constitutional standard. ${ }^{12}$ McConnell, I think, may be faulted for arguing that this counterrevolution took place at a single historical moment; actually the political and judicial retreat from Reconstruction began earlier than 1876 and was not completed until the 1890s. Overall, however, Ackerman's attempt to refute $\mathrm{McC}$ Connell persuades me that McConnell is correct.

Ackerman insists that despite the undoubted deprivations of blacks' rights, "We the People" never confirmed the substitution of a racist constitution for the egalitarian one devised during Reconstruction. ${ }^{13}$

10. See FONER, supra note 8, at $116-23$.

11. See 2 ACKERMAN, supra note 1 , at 471 n.126.

12. See Michael McConnell, The Forgotten Constitutional Moment, 11 ConsT. COMMENTARY 115 (1994).

13. See 2 ACKERMAN, supra note 1, at 471 n.126. 
Frankly, this strikes me as wishful thinking. To be sure, no single election turned on this issue. But there is no question that by the turn of the century, white public opinion had abandoned the egalitarian vision of citizenship spawned by the Civil War, and had revived definitions of American freedom and nationality based on race. By 1900, the language of "race"race conflict, race feeling, race problems-had assumed a central place in American public discourse. The putative inborn capacity of one or another "races" was commonly invoked to explain everything from the standard of living of various groups of workers to the ability or inability of different peoples to participate in American democracy. The new situation was most evident in the condition of black Americans. By the early twentieth century, a new system of racial subordination had come into being in the South. The disenfranchisement of Southern blacks (along with a considerable number of poor white voters), which began in Mississippi in 1890, not only halted and reversed the long trend toward expanding the suffrage, but transformed Deep South states into political rotten boroughs whose representatives in Congress would long wield far greater power on the national scene than their tiny electorates warranted-a constitutional change that would have a tremendous impact on the actual workings of the New Deal. Southern whites, however, did not create their new system of white supremacy alone. The effective nullification of the Fourteenth and Fifteenth Amendments occurred with the full acquiescence of the North, as evidenced in electoral campaigns, political treatises, and innumerable court decisions. ${ }^{14}$ While certainly reprehensible by modern standards, this constitutional counterrevolution would seem to meet Ackerman's standard for a redefinition of constitutional law and practice that achieved legitimacy within the political nation.

With black disenfranchisement and the simultaneous Chinese exclusion, the rigid segmentation of the job market along racial and ethnic lines, and the emergence of an imperial policy toward non-white peoples overseas, the polity and economy were more thoroughly racialized at the dawn of the twentieth century than at any other point in American history. Ackerman's claim that the Fourteenth Amendment achieved permanent legitimation during the Grant administration can only be maintained by denuding the Amendment of much of its meaning, or skipping over the Jim Crow-era entirely. Indeed, Ackerman's definition of legitimacy is curiously ambiguous. At some points, legitimacy seems to be a legal concept, achieved when the Fourteenth Amendment is recognized by the Supreme Court as part of the Constitution despite the irregularities of its ratification. (This happened, Ackerman argues, in 1873 in The Slaughter-House

14. See RAYFord LOGAN, THE BETRAYAL OF THE NEGRO FROM RUTHERFORD B. HAYES TO WOODROW WIISON (1965). 
Cases. $)^{15}$ At others, legitimacy means broad public acceptance of the substance of constitutional change. Here, Ackerman's previous inattention to the substantive meaning of the Amendment comes back to haunt his analysis. For if racial justice, secured if necessary by the federal government, is the essence of the Fourteenth Amendment, one wonders whether it is really accurate to claim that the constitutional changes of Reconstruction ever achieved constitutional "legitimacy." Certainly, if they did so, it was not until the 1960s, and then not so much as the result of presidential action and congressional debates, but of the greatest mass movement of the twentieth century. Constitutional creativity, in other words, did not end with the New Deal, and the process was not limited to developments, to use a modern phrase, "inside the Beltway."

The tortured history of the Reconstruction Amendments might also lead Ackerman to reconsider the Whiggish narrative of progress that underpins these volumes. Among the most charming features of Ackerman's approach is that he really believes in that quaint idea, Progress. In his narrative, when confronted with a crisis, leaders and the "People" have responded with a burst of constitutional creativity, thus changing our fundamental law so as to come to terms with problems left unresolved by the Founding Fathers. Such revolutions, he insists, ought to be welcomed, not feared, for they are essential to the health of the body politic and of American society. But, as Thomas Wentworth Higginson observed in the midst of the Civil War, revolutions may go backward. ${ }^{16}$ A full account of the process of constitutional innovation would have to include not only revolutions but counterrevolutions, not only moments when constitutional rights are expanded, but times when they have been taken away.

15. See 2 ACKERMAN, supra note 1 , at 252, 268.

16. See WILLIE LEE ROSE, REHEARSAL FOR RECONSTRUCTION: THE PORT ROYAL EXPERIMENT 408 (1964). 
